\title{
Estimation of post-harvest losses of major vegetables in Karnataka- Amanagement appraisal
}

\section{D.H. MITRANNAVAR AND R.A. YELEDALLI}

\begin{abstract}
Agriculture occupies the central place in rural life. The contribution of agriculture towards national income was about 15.5 per cent in 2010-2011 (GoI 2007-12). Horticultural crops include large varieties of fruits and vegetables, flowers, plantation spice crops, medicinal and aromatic plants, roots and tuber crops. The present study conducted in Karnataka state aims at estimation of post-harvest losses in major vegetables. The results of the study revealed that the overall loss at different stages was around $177.71 \mathrm{~kg}(22.86 \%)$ in potato. The maximum loss was found to occur at the commission agent-cum-wholesaler level. The overall loss at different stages was around 108.53 $\mathrm{kg}(27.44 \%)$ in tomato. The overall loss at different stages was around $72.00 \mathrm{~kg}(21.61 \%)$ in brinjal. The maximum loss was found to occur at the retail level. The overall loss at different stages was around $67.56 \mathrm{~kg}(22.36 \%)$ in beans. The maximum loss was found to occur at the commission agent-cum-wholesaler level. The overall loss at different stages was around $138.45 \mathrm{~kg}(16.68 \%)$ in onion. The maximum loss was found to occur at the commission agent-cum-wholesaler level.
\end{abstract}

KEY WORDS : Farmers, Market functionaries, Post-harvest losses, Vegetables

How to cite this paper : Mitrannavar, D.H. and Yeledalli, R.A. (2014). Estimation of post-harvest losses of major vegetables in Karnataka- A management appraisal. Internat. J. Com. \& Bus. Manage., 7(2) : 349-353.

\section{MEMBERS OF THE RESEARCH FORUM}

Correspondence to:

D.H. MITRANNAVAR, Department of Agribusiness Management, University of Agricultural Sciences, DHARWAD (KARNATAKA) INDIA

Email: mitrudh@ rediffmail.com

Authors' affiliations:

R.A. YELEDALLI, Department of Agribusiness Management, University of Agricultural Sciences, DHARWAD (KARNATAKA) INDIA 